\title{
Application of multivariate statistical on quality of amazon honey from Apis sp. vs Melipona sp.
}

Aplicação da estatística multivariada na qualidade de mel amazônico de Apis sp. vs Melipona sp.

\author{
P. W. P. Gomes ${ }^{1 *}$; A. J. B. Muribeca ${ }^{1}$; J. Moreira-Neto ${ }^{2}$; P. W. P. Gomes ${ }^{3}$; E. R. \\ S. Pereira ${ }^{4}$; L. H. S. Martins ${ }^{5}$ \\ Faculty of Chemistry, Federal University of Pará, 66075-110, Belém-PA, Brazil. \\ ${ }^{2}$ Engineering Department, Federal University of Lavras, 37200-000 Lavras-MG, Brazil. \\ ${ }^{3}$ Center for Natural Sciences and Technology, State University of Pará, 66095-100 Belém-PA, Brazil. \\ ${ }^{4}$ Department of Health Sciences, Federal University of Pará, 66075-110 Belém-PA, Brazil. \\ ${ }^{5}$ Faculty of Food Engineering, Federal University of Pará, 66075-110 Belém-PA, Brazil \\ *wenderufpa@hotmail.com \\ (Recebido em 16 de agosto de 2019; aceito em 23 de dezembro de 2019)
}

\begin{abstract}
This paper aimed to study the quality of honey from genus Apis sp. and Melipona sp from Archipelago of Marajo. The honey was collected from two cities (Soure and Salvaterra). All samples were analyzed for their physicochemical composition, phenolic compounds, antioxidant activity, and analyses of standard quality control of honey. All data were subjected to statistical analysis of Tukey (95\%), Person correlation and Multivariate (Principal Component Analysis (PCA) and Grouping Analysis (HCA)). The study resulted in a significant antioxidant potential from Apis sp. $\left(\mathrm{EC}_{50}=21.14 \pm 142.90 \mu \mathrm{g} \cdot \mathrm{mL}^{-1}\right)$ and Melipona sp. $\left(\mathrm{EC}_{50}=\right.$ $\left.13.62 \pm 198.11 \mu \mathrm{g} \cdot \mathrm{mL}^{-1}\right)$ by the DPPH (2,2- diphenyl-1-picrylhydrazyl) radical sequestration method. All studied honey presented excellent quality and the presence of secondary metabolites belonging to the class of total phenolic (ranged $27.01 \pm 1.01$ to $56.09 \pm 1.32 \mathrm{mg} \mathrm{GAE} 100 \mathrm{~g} \mathrm{~g}^{-1}$ ). In relation to physicochemical and microbiological parameters, all the samples were adequate for use and consumption. The multivariate analysis proved to be a very useful tool for the analysis of different samples of honey. The honey quality is very important since Marajo is a region with great potential for honey production that needs standardization of those products, which deserve greater attention and appreciation.
\end{abstract}

Palavras-chave: Honey, multivariate analysis, antioxidant activity.

O presente trabalho teve como objetivo estudar a qualidade de méis de abelha do gênero Apis sp. and Melipona sp. oriúndos do Arquipélago do Marajó. O mel foi coletado de duas cidades (Soure e Salvaterra). Todas as amostras foram analisadas em relação a composição físico-química, compostos fenólicos, atividade antioxidante e análises padrão de qualidade do mel. Todos os dados foram submetidos a análises estatísticas de Tukey (95\%), Correlação de Pearson e Análise Multivariada- (Principal Component Analysis - PCA) e Grouping Analysis (HCA). O estudo resultou em um significante potencial antioxidante do gênero Apis sp. $\left(\mathrm{EC}_{50}=21.14 \pm 142.90 \mu \mathrm{g} \cdot \mathrm{mL}^{-1}\right)$ e Melipona sp. $\left(\mathrm{EC}_{50}=13.62 \pm 198.11 \mu \mathrm{g} \cdot \mathrm{mL}^{-1}\right)$ pelo método de sequestro de radical DPPH (2,2- diphenyl-1-picrylhydrazyl). Todas as amostras de mel estudadas apresentaram excelente qualidade e a presença de metabólitos secundários pertencentes a classe dos fenóis totais (faixa $27.01 \pm 1.01$ a $56.09 \pm 1.32 \mathrm{mg} \mathrm{GAE} .100 \mathrm{~g}^{-1}$ ). Em relação aos parâmetros microbiológicos e físico-químicos, todas as amostras estiveram adequadas ao uso e consumo. A análise multivariada é uma ferramenta útil para analisar diferentes amostras de méis. A qualidade do mel é muito importante, visto que, o Marajó é uma região com grande potencial de produção de mel que necessita de padronização e merece uma maior atenção e apreciação.

Keywords: Mel, Análise Multivariada, Atividade Antioxidante. 


\section{INTRODUCTION}

Brazil produced 41,600 tons of honey in 3,879 municipalities in 2017, an increase of 5.0\% over the previous year. The production value was $\mathrm{R} \$ 513.9$ million. The Pará state reaching 524 tons, presenting $2.3 \%$ of the national production in 2016 [1].

The breeding of bees in Brazil today can be divided into two distinct practices, Beekeeping and Meliponiculture. Beekeeping is the activity that consists in the handling of the bee Apis mellifera and the products coming from its hive. Meliponiculture is the rational creation of "stingless bees" or also called "meliponinas". The absence of the sting is a specific characteristic of these bees, which are still little known, but nonetheless, are very important due to their pollinating role for millions of years. In Brazil, there is legislation recommending quality standards for honey [2], pollen, propolis and royal jelly $[3,4]$.

Studies have already shown the antibacterial, antifungal and antiviral action of honey, which is possible due to its low $\mathrm{pH}$, high concentration of sugars, hydrogen peroxide and the presence of some phytochemical compounds (phenolic compounds) [5]. Nowadays, the interest in new food products with functional properties has grown considerably. Regarding honeys, there are welldefined products on the markets, where they depend heavily on the level of satisfaction and quality expectations of consumers [6].

Studies have certified that the phenolic compounds present in honey can come from nectar of flowers, pollen, propolis and/or beeswax and, thus, the composition of the honey will differentiate according to its origin. It was also verified that the content of phenolic compounds in the honey could be quite affected according to its floral and geographical origin, as well as the climatic characteristics of the place where the honey is collected [7].

It is well established in the literature that honey composition varies greatly according to its botanical and geographic origin, bee species and climatic conditions at the place of production [8, 9]. Moreover, this makes the search for honey of different places and bee species interesting for study. The Amazon region of Brazil differs from other Brazilian regions in the climate and flora, and the northern region occupies the tenth place in the national production ranking [10].

In the last decade, multivariate statistics were applied to characterize and evaluate biological parameters such as water quality. According to previous research, multivariate statistical methods have proved to be a useful tool for extracting meaningful information from a dataset and optimizing monitoring networks [11].

The aim of this paper was to characterize and to compare honey of the genus Apis sp. and Melipona sp. produced in the Amazon region (Soure and Salvaterra) in terms of composition, phenolic compounds and antioxidant activity using statistical tools such as Principal Component Analysis (PCA), Hierarchical analysis (HCA) and Tukey analysis for data treatment.

\section{MATERIALS AND METHODS}

\subsection{FEEDSTOCK}

A total of 12 samples of polyfloral honey from two different genera of bees (Apis sp. and Melipona sp.) were used in this study. Honey samples were provided by beekeepers and collected between June and September in 2017 in the municipalities of Salvaterra $\left(0^{\circ} 45^{\prime} 10.52\right.$ "S; 48 31 '22.5" $\mathrm{W})$ and Soure $\left(0^{\circ} 44^{\prime} 17.55\right.$ "S; 48 $\left.29,41.66^{\prime \prime} \mathrm{W}\right)$, both belonging to the region of Marajó-PA. The municipalities were selected based on their potential melliferous and poliniferous.

The experimental design for the collection of honey was based on the eucalyptus (Eucalyptus spp.) and orange (Citrus spp.) phenology, which show the highest and most intense flowering peak in the period from June to September [12]. 
The samples were selected according to the predominance of sunny periods. The feedstock was obtained by its directly collecting in the hives, these samples were centrifuged for 3,024 G-force; later they were packed in properly sterilized glass bottles of $500 \mathrm{~mL}$.

\subsection{MICROBIOLOGICAL ANALYSIS}

The microbiological analysis were carried out for the 12 honey samples [13] methodology in terms of total coliforms, thermotolerant coliforms, and yeasts and molds. Following Brasil (2019) [14] standards were evaluated in accordance with Resolution $\mathrm{n}^{\circ} 12$.

\subsection{PHYSICOCHEMICAL COMPOSITION}

For the moisture determination, was used the refractometric method with the aid of Chataway table, where it uses the sample refractive index to be converted to a moisture percentage [15]. The ashes were determined according to the protocol $\mathrm{n}^{\circ} 920,181$ by AOAC methodology [16]. The color was measured in a spectrophotometer (Bel-Photonics $\left.{ }^{\circledR}\right)$. The honey's $\mathrm{pH}$ was determined with a pHmeter (Nova-instruments ${ }^{\circledR}$ ). The free acidity was determined according to method no. 962.19 by AOAC [16]. Reducing sugars were determined by the 3.5-dinitrosalicylic acid (DNS) method [17].

Fructose was quantified by the Selliwanoff reagent [18]. The insoluble solids contents were determined according to the recommendation of the Ministry of Agriculture and Supply [2].

\subsection{TOTAL PHENOLIC CONTENT AND ANTIOXIDANT ACTIVITY}

The phenolic content was quantified by the method using the Folin-Ciocalteau reagent [19]. For the determination of the antioxidant [20] activity of honey, initially, a methanolic solution of 100 $\mu \mathrm{M}$ DPPH was prepared and stored in an amber bottle and kept under refrigeration $\left(4^{\circ} \mathrm{C}\right)$ until analysis. For the performance of the assays, the solution was adjusted to an absorbance of about $0.625 \mathrm{~nm}$ with the addition of methanol. Methanol solutions of honey were prepared that varied in concentrations of 5 to $120 \mathrm{mg} \cdot \mathrm{mL}^{-1}$. Aliquots of $2100 \mu \mathrm{L}$ of each concentration were mixed with $900 \mu \mathrm{L}$ of DPPH. The mixture was homogenized and allowed to stand, in the dark, for 30 minutes. A negative control was prepared, consisting of $900 \mu \mathrm{L}$ of $\mu \mathrm{M}$ DPPH and $2100 \mu \mathrm{L}$ of methanol. Subsequently, a UV-Vis and read spectrophotometrically at $517 \mathrm{~nm}$, the results were converted to the percentage of antioxidant activity following Equation 1:

$$
\mathrm{AA} \%=\left(\frac{\mathrm{ABS}_{\text {control }}-\mathrm{ABS}_{\text {sample }}}{\mathrm{ABS}_{\text {control }}}\right) \cdot 100
$$

Notes Equation 1: $\mathrm{Abs}_{\text {control }}$ is the absorbance of the negative control and $\mathrm{Abs}_{\text {sample }}$ is the absorbance of DPPH after reacting with the honey.

\subsection{DIASTASE ACTIVITY}

Diastase activity was determined by spectrophotometer reading [21], is used by discoloration of a starch solution, iodine, and honey under controlled conditions.

\subsection{STATISTICAL ANALYSIS}

\subsubsection{Tukey analysis and Pearson correlation}


The results of the analysis performed for the honey of different bees were submitted to analysis of variance (ANOVA) and the means calculations by the Tukey test at $5 \%$ probability with the aid of the statistical software Statistica 7.0 [22].

Pearson's correlation between the chemical and physicochemical variables between samples of honey from different bees and different places was also performed. The results were expressed as mean \pm standard deviation, coefficient of variation, maximum and minimum values.

\subsubsection{Principal Component Analysis (PCA) and Grouping Analysis (HCA)}

For this study, the following analyzes were performed: Principal Component Analysis (PCA), Hierarchical Cluster Analysis (HCA) where 09 (nine) physical-chemical parameters were evaluated: reducing sugars, fructose, ash, $\mathrm{pH}$, acidity, humidity, diastasis activity, total phenols and water insoluble solids. Data interpretation was performed using Statistica 7.0 software [22].

\section{RESULTS AND DISCUSSION}

\subsection{MICROBIOLOGICAL ANALYSIS}

The microbiological analysis results are presented in Table 1 , the assays were performed for more probable numbers to coliforms at $35^{\circ} \mathrm{C}$ and $45^{\circ} \mathrm{C}(\mathrm{NMP} / \mathrm{g})$ and yeasts and molds.

The presence of microorganisms from the coliforms group was not observed in any of the analyzed honey samples, thus dispensing with the need for tests for Escherichia coli (EC). Other authors obtained similar values to the present study, which were <3.0 CFU/g. Comparing the microbiological characteristics of 21 honeyproduced in Brazil Northeastern Region (Bahia State) [23], also found results lower than 3.0 colony-forming units; Investigated the microbiological profile of 20 honey samples from Ceará and 38 samples from Piauí and found similar results [24].

The yeasts and molds analyze (UFC/g) showed an incidence ranging from $\left(6.0 \times 10^{3}\right.$ to $2.0 \mathrm{x}$ $10^{2}$ ), values below that established by current legislation, it is worth noting that $25 \%$ of the samples investigated did not show the activity of these microorganisms. 
Table 1: Microbiological analysis of the 12 honey samples analyzed.

\begin{tabular}{|c|c|c|c|c|c|c|}
\hline Sample & Location* & Genre & Collection area & $\begin{array}{l}\text { Total Coliforms } \\
\quad\left(M P N . g^{-1}\right)\end{array}$ & $\begin{array}{c}\text { Thermotolerant } \\
\text { Coliform } \\
\left(\text { MPN.g }{ }^{-1}\right)\end{array}$ & $\begin{array}{l}\text { Yeasts and Molds } \\
\quad\left(\text { CFU.g } \text { g }^{-1}\right)\end{array}$ \\
\hline $\mathbf{A 1}$ & Soure & Apis sp. & Primary forest & $<3.00$ & $<3.00$ & Absent \\
\hline A2 & Soure & Apis sp. & Primary forest & $<3.00$ & $<3.00$ & $8.00 \times 10^{2}$ \\
\hline A3 & Salvaterra & Apis sp. & Primary forest & $<3.00$ & $<3.00$ & $2.00 \times 10^{2}$ \\
\hline A4 & Soure & Apis sp. & Mangrove & $<3.00$ & $<3.00$ & $6.00 \times 10^{3}$ \\
\hline A5 & Salvaterra & Apis sp. & Mangrove & $<3.00$ & $<3.00$ & Absent \\
\hline A6 & Soure & Apis sp. & Primary forest & $<3,00$ & $<3.00$ & $1.00 \times 10^{3}$ \\
\hline M7 & Soure & Melipona sp. & Primary forest & $<3.00$ & $<3.00$ & Absent \\
\hline M8 & Soure & Melipona sp. & Primary forest & $<3.00$ & $<3.00$ & $7.00 \times 10^{2}$ \\
\hline M9 & Salvaterra & Melipona sp. & Primary forest & $<3.00$ & $<3.00$ & $1.00 \times 10^{3}$ \\
\hline M10 & Soure & Melipona sp. & Primary forest & $<3.00$ & $<3.00$ & $1.00 \times 10^{3}$ \\
\hline M11 & Soure & Melipona sp. & Primary forest & $<3.00$ & $<3.00$ & $4.00 \times 10^{2}$ \\
\hline M12 & Salvaterra & Melipona sp. & Primary forest & $<3.00$ & $<3.00$ & $1.00 \times 10^{3}$ \\
\hline
\end{tabular}

MPN: Most Probable Number; CFU: Colony-Forming Unit. *Municipalities located in the state of Pará, Brazil. 


\subsection{PHYSICOCHEMICAL PARAMETERS}

The values (mean \pm standard deviation) found for physicochemical and total phenolic compound of the 12 honey samples are presented in Figure 1 and Table 2, respectively.

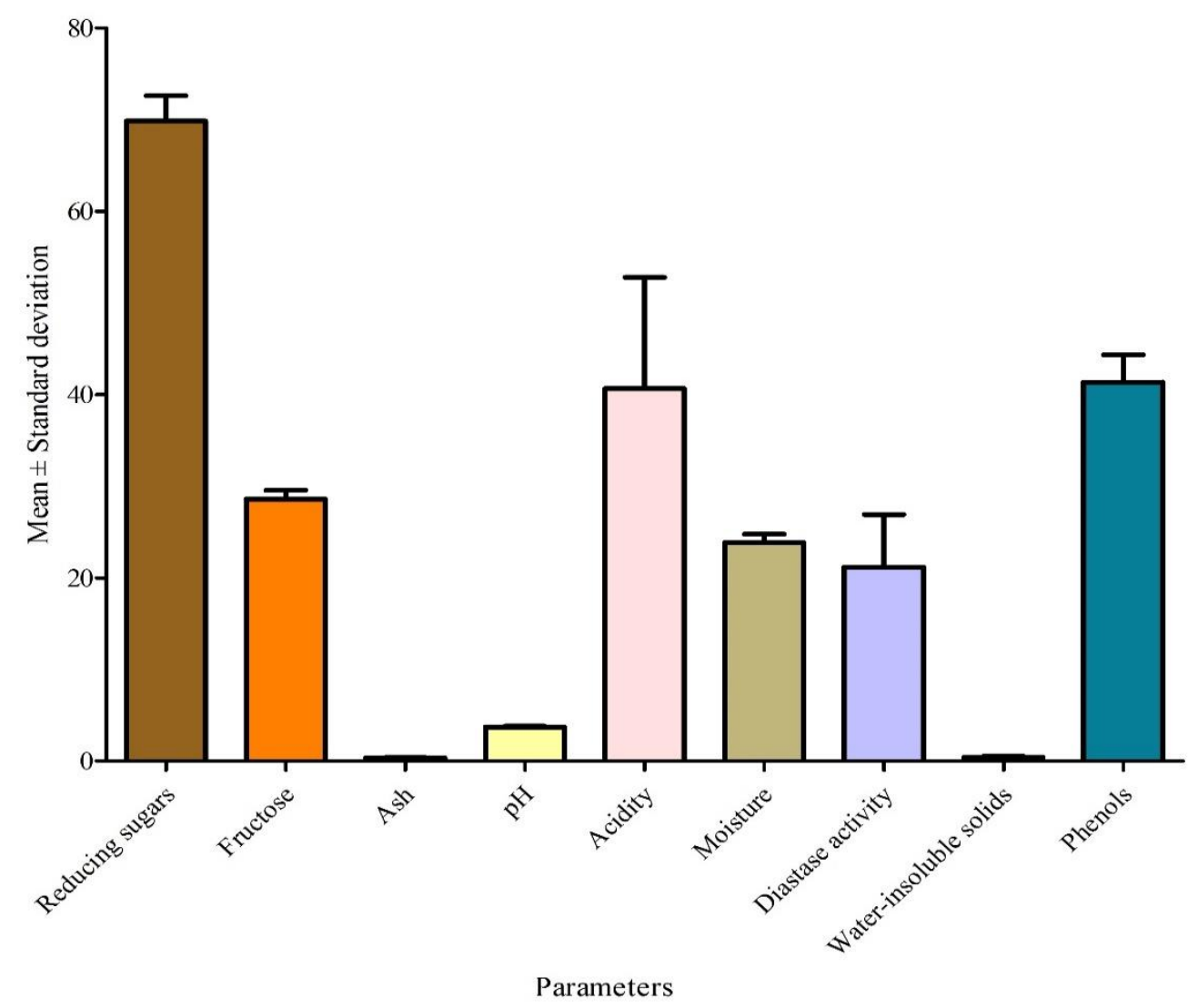

Figure 1: Mean pattern of physicochemical parameters of honey from two gender.

The obtained values in this work were compared with the Brazilian and international Legislation, which establishes standard values for the quality of the product control [2,24]. Diastasis in the analyzed honey ranged from 4.10 to 67.23 on the Gothe scale with a mean of 22.97. Brazilian legislation requires that the diastasis index be greater than 8 or 3 Gothe units, with no standard for maximum value. The average value obtained for reducing sugars was $70.21 \mathrm{~g} .100 \mathrm{~g}^{-1}$, being in the range of $\left(57.01-87.12 \mathrm{~g} .100 \mathrm{~g}^{-1}\right)$, respectively.

In relation to the diastase activity [26], that enzymes present in some honey are also responsible for changes in their physicochemical and nutritional characteristics during storage. Honey in its formation process contains plant and insect enzymes: invertase, amylase (diastase), glucose, oxidase, catalase, and phosphatase. Invertase incorporated into nectar by the saliva of bees transforms sugars, in particular, sucrose, which results in a mixture of glucose and fructose. Diastase actions lead to the transformation of $3 / 4$ sucrose. So, the older the honey, the less sucrose it will contain. Amylase is very important in detecting possible heating that honey may have undergone in its commercial process because the amylase is very unstable against temperature rises. However, the amylase should be considered to deteriorate at room temperature when storage is prolonged and therefore functions as an indication of the age and validity of honey [22]. It can be observed in Table 2 that the majority of the parameters presented a significant difference between the samples, proving that the difference in honey composition in relation to bee origin, location, etc. actually occurs. 
Table 2: Physicochemical parameters (mean \pm standard deviation) of the 12 honey samples analyzed.

\begin{tabular}{|c|c|c|c|c|c|c|c|c|c|}
\hline Sample & $\begin{array}{l}\text { Reducing sugars } \\
\quad\left(\text { g.100 g } \mathrm{g}^{-1}\right)\end{array}$ & $\begin{array}{l}\text { Fructose } \\
\left(\text { g.100 g }^{-1}\right)\end{array}$ & $\operatorname{Ash}\left(\mathrm{g} .100 \mathrm{~g}^{-1}\right)$ & pH & $\begin{array}{c}\text { Acidity } \\
\left(\mathbf{m E q . 1 0 0} \mathrm{g}^{-1}\right)\end{array}$ & $\begin{array}{l}\text { Moisture } \\
\left(\text { g.100 g }{ }^{-1}\right)\end{array}$ & $\begin{array}{l}\text { Diastase } \\
\text { activity } \\
\text { (Gothe) }\end{array}$ & $\begin{array}{l}\text { Water-isoluble } \\
\text { solids }(\text { g.100 g-1) }\end{array}$ & Color \\
\hline $\mathbf{A 1}$ & $69.20 \pm 1.02^{\mathrm{a}}$ & $25.21 \pm 3.67^{\mathrm{a}}$ & $0.55 \pm 0.07^{\mathrm{a}}$ & $3.54 \pm 0.03^{\mathrm{a}}$ & $119.6 \pm 2.50^{\mathrm{a}}$ & $29.71 \pm 0.20^{\mathrm{a}}$ & $13.01 \pm 0.90^{\mathrm{a}}$ & $0.142 \pm 0.01^{\mathrm{a}}$ & 107.13 amber \\
\hline A2 & $70.80 \pm 2.01^{\mathrm{b}}$ & $24.70 \pm 0.01^{\mathrm{b}}$ & $0.52 \pm 0.13^{\mathrm{b}}$ & $3.77 \pm 0.01^{\mathrm{b}}$ & $15.00 \pm 0.03^{\mathrm{b}}$ & $23.37 \pm 0.01^{\mathrm{b}}$ & $23.01 \pm 1.01^{\mathrm{b}}$ & $0.415 \pm 0.45^{\mathrm{b}}$ & $\begin{array}{c}188.96 \text { dark } \\
\text { amber }\end{array}$ \\
\hline A3 & $69.00 \pm 2.10^{c}$ & $30.09 \pm 2.10^{\mathrm{c}}$ & $0.15 \pm 0.11^{\mathrm{c}}$ & $3.77 \pm 0.01^{\mathrm{b}}$ & $33.25 \pm 0.05^{\mathrm{c}}$ & $21.39 \pm 0.02^{\mathrm{c}}$ & $67.23 \pm 2.20^{\mathrm{c}}$ & $0.210 \pm 0.04^{\mathrm{c}}$ & $\begin{array}{c}215.08 \text { dark } \\
\text { amber }\end{array}$ \\
\hline A4 & $65.90 \pm 1.40^{\mathrm{d}}$ & $31.71 \pm 1.40^{\mathrm{d}}$ & $0.16 \pm 0.10^{\mathrm{d}}$ & $3.88 \pm 0.11^{\mathrm{c}}$ & $23.79 \pm 1.39^{\mathrm{d}}$ & $20.87 \pm 0.10^{\mathrm{d}}$ & $23.32 \pm 2.10^{\mathrm{d}}$ & $0.370 \pm 0.08^{\mathrm{d}}$ & $\begin{array}{l}55.51 \text { light } \\
\text { amber }\end{array}$ \\
\hline A5 & $87.12 \pm 1.71^{\mathrm{e}}$ & $25.90 \pm 1.20^{\mathrm{e}}$ & $0.11 \pm 0.12^{\mathrm{e}}$ & $3.12 \pm 0.13^{\mathrm{d}}$ & $23.30 \pm 1.66^{\mathrm{d}}$ & $19.10 \pm 0.46^{\mathrm{e}}$ & $33.10 \pm 1.23^{\mathrm{e}}$ & $0.363 \pm 0.18^{\mathrm{e}}$ & $\begin{array}{l}3.89 \text { white- } \\
\text { water }\end{array}$ \\
\hline A6 & $70.07 \pm 1.65^{\mathrm{f}}$ & $33.12 \pm 1.23^{\mathrm{f}}$ & $0.07 \pm 0.01^{\mathrm{f}}$ & $3.87 \pm 0.04^{\mathrm{c}}$ & $14.17 \pm 0.05^{\mathrm{e}}$ & $23.63 \pm 0.14^{\mathrm{f}}$ & $9.44 \pm 0.10^{\mathrm{f}}$ & $0.730 \pm 0.02^{\mathrm{f}}$ & $\begin{array}{c}145.76 \text { dark } \\
\text { amber }\end{array}$ \\
\hline M7 & $84.01 \pm 1.01^{\mathrm{g}}$ & $32.02 \pm 2.02^{\mathrm{g}}$ & $0.04 \pm 0.05^{\mathrm{g}}$ & $4.15 \pm 0.04^{\mathrm{e}}$ & $12.29 \pm 2.68^{\mathrm{f}}$ & $20.44 \pm 0.10^{\mathrm{d}}$ & $8.90 \pm 1.55^{\mathrm{g}}$ & $0.335 \pm 0.14^{\mathrm{g}}$ & $\begin{array}{c}180.05 \text { dark } \\
\text { amber }\end{array}$ \\
\hline M8 & $67.09 \pm 1.67^{\mathrm{h}}$ & $23.10 \pm 1.25^{\mathrm{h}}$ & $0.09 \pm 0.07^{\mathrm{h}}$ & $3.28 \pm 0.03^{f}$ & $33.25 \pm 0.01^{\mathrm{c}}$ & $25.71 \pm 0.01^{\mathrm{g}}$ & $4.10 \pm 1.01^{\mathrm{h}}$ & $0.165 \pm 0.04^{\mathrm{h}}$ & $\begin{array}{c}125.95 \text { dark } \\
\text { amber }\end{array}$ \\
\hline M9 & $57.01 \pm 0.03^{\mathrm{i}}$ & $23.71 \pm 1.80^{\mathrm{i}}$ & $0.52 \pm 0.03^{\mathrm{b}}$ & $3.50 \pm 0.01 \mathrm{~g}$ & $136.4 \pm 1.90^{\mathrm{g}}$ & $29.03 \pm 0.10^{\mathrm{h}}$ & $15.89 \pm 1.20^{\mathrm{i}}$ & $0.075 \pm 0.01 \mathrm{i}$ & $\begin{array}{c}189.46 \text { dark } \\
\text { amber }\end{array}$ \\
\hline M10 & $65.00 \pm 1.01^{\mathrm{j}}$ & $37.22 \pm 2.10^{\mathrm{j}}$ & $0.16 \pm 0.02^{\mathrm{d}}$ & $3.99 \pm 0.02^{\mathrm{h}}$ & $17.44 \pm 2.48^{\mathrm{h}}$ & $22.50 \pm 0.30^{\mathrm{i}}$ & $21.73 \pm 1.96^{\mathrm{j}}$ & $0.315 \pm 0.26^{\mathrm{j}}$ & $\begin{array}{l}235.76 \text { dark } \\
\text { amber }\end{array}$ \\
\hline M11 & $60.10 \pm 2.92^{\mathrm{k}}$ & $22.09 \pm 0.09^{k}$ & $0.04 \pm 0.13^{\mathrm{g}}$ & $3.29 \pm 0.02^{\mathrm{f}}$ & $42.50 \pm 0.10^{\mathrm{i}}$ & $24.56 \pm 0.23^{\mathrm{j}}$ & $33.01 \pm 3.10^{\mathrm{k}}$ & $1.560 \pm 0.15^{\mathrm{k}}$ & $\begin{array}{c}254.95 \text { dark } \\
\text { amber }\end{array}$ \\
\hline M12 & $77.23 \pm 2.02_{1}$ & $29.60 \pm 1.97^{1}$ & $0.01 \pm 0.01^{\mathrm{e}}$ & $4.38 \pm 0.10^{\mathrm{i}}$ & $14.96 \pm 1.52^{\mathrm{j}}$ & $25.35 \pm 0.10^{\mathrm{k}}$ & $4.15 \pm 0.21^{1}$ & $0.235 \pm 0.17^{1}$ & $\begin{array}{c}160.37 \text { dark } \\
\text { amber }\end{array}$ \\
\hline Media & 70,21 & 28.07 & 0.21 & 3.65 & 42.81 & 23.66 & 22.97 & 0.390 & 155.24 \\
\hline Minimum & 57,01 & 22.09 & 0.04 & 3.12 & 12.29 & 19.10 & 4.100 & 0.075 & 3.89 \\
\hline Maximum & 87,12 & 37.22 & 0.55 & 4.15 & 136.4 & 29.71 & 67.23 & 1.560 & 254.95 \\
\hline${ }^{a}$ Legislation & $\geq 65.0$ & $*$ & $\leq 0.6$ & $*$ & $\leq 50,0$ & $\leq 20.0$ & $\geq 8$ & $\leq 0.1$ & $*$ \\
\hline${ }^{b}$ Legislation & $\geq 60.0$ & $*$ & $*$ & $*$ & $\leq 50.0$ & $\leq 20.0$ & $*$ & $\leq 0.1$ & $*$ \\
\hline
\end{tabular}

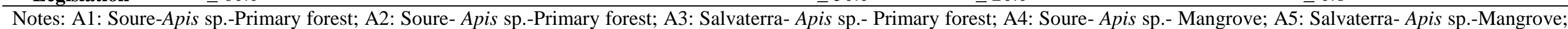

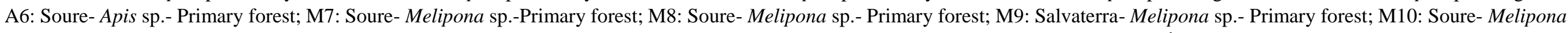

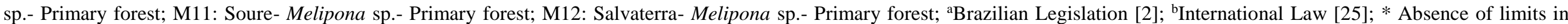
legislation; ** not detected; mg GAE: Milligrams gallic acid equivalente. Equal letters in the same column did not differ significantly from each other by the Tukey test (p>0.05). 
From the analyzed samples, the sample M9 was the only below the minimum recommended by the National [2] and International [25] Legislation. However, it is within the minimum limit proposed by Villas-Bôas and Malaspina (2005) [27] for meliponine honey that establishes $50 \%$. For fructose, the values found ranged from 22.09 to $37.22 \mathrm{~g} .100 \mathrm{~g}^{-1}$, with an average of $28.07 \mathrm{~g} .100$ $\mathrm{g}^{-1}$. This parameter does not have values established by the current legislation; however, it is an important index to be analyzed in honey, since its concentration directly influences its taste and crystallization [28].

The moisture contents in the studied honey ranged from $19.10 \mathrm{~g} .100 \mathrm{~g}^{-1}$ to $29.71 \mathrm{~g} .100 \mathrm{~g}^{-1}$, with an average of $23.66 \mathrm{~g} .100 \mathrm{~g}^{-1}$. The values show that approximately $92 \%$ of the samples are above acceptable moisture content when compared to the National [2] and International [25] Legislation standards, where they set the maximum limit of $20 \mathrm{~g} \cdot 100 \mathrm{~g}-{ }^{1}$. However, several researchers in different types of honey have already found levels above these values [9, 29, 30, 31, 32].

The colors analyze for the 12 samples of honeyshows that all of them are within the standards of the National Legislation [2], where it establishes the variation from white-water to dark amber. The obtained results demonstrate the predominance of the dark amber color for both bee genus studied (Apis and Melipona) with the highlight for the honey of the genus Melipona. This genus presented a percentage equal to $100 \%$ for dark amber color, suggesting the dark color is relatively mediated by the type of frequented flora, being the darker honey characterized by eucalyptus flowers, among others [33].

The $\mathrm{pH}$ ranged from 3.12 to 4.15 with an average of 3.65; This is an auxiliary parameter for total acidity in meq. $\mathrm{Kg}^{-1}$, where it is shown that approximately $83 \%$ of the analyzed samples are fully in agreement with the values established by national [2] and international [25] Legislation. With a variance of 12.29 meq. $\mathrm{kg}^{-1}$ at 136.4 meq. $\mathrm{kg}^{-1}$ (average of 42.81 meq. $\mathrm{kg}^{-1}$ ) where the maximum allowed is 50 meq. $\mathrm{kg}^{-1}$. Analyzed honey from Salvaterra - PA city [34] and found similar values, ranging from 21.47 to 95.78 (average of 44.33 meq. $\mathrm{kg}^{-1}$ ), and this author points out that the values may be correlated with the honey fermentation process. Analyzed honey from Soure - PA City [33], and found an average acidity of 27.70 meq. $\mathrm{kg}^{-1}$, the same author emphasizes that the acidity values can also be proportional to the nectar content in the samples and soil conditions, and although it is known that the climatic conditions also have an influence in this parameter.

The insoluble solids contents indicate the honey's degree of purity, the values found ranged from 0.075 to $1.56 \mathrm{~g} / 100 \mathrm{~g}$ (average of $0.39 \%$ ). Compared with the values established in national and international legislation, $90 \%$ of the analyzed samples were found to be non-conforming, but with similarities in literature. In literature [35] $100 \%$ of the samples in total disagreement with the national and international standard, obtaining variation from 0.53 to $1.58 \mathrm{~g} .100 \mathrm{~g} \mathrm{~g}^{-1}$ (average of 0.87 g. $\left.100 \mathrm{~g}^{-1}\right)$.

The ash values ranged from $0.04-0.55 \mathrm{~g} .100 \mathrm{~g}^{-1}$, with the M9 sample presenting a percentage higher than 0.6 g. $100 \mathrm{~g}^{-1}$, the maximum value allowed by the legislation. In literature [35], when analyzing honey samples from the Russas-CE City, also registered non-standard values, ranging from 0.02 to $2.67 \mathrm{~g} .100 \mathrm{~g}^{-1}$ (average of $1.15 \mathrm{~g} .100 \mathrm{~g} \mathrm{~g}^{-1}$ ). The average ash content in the samples analyzed was $0.21 \mathrm{~g} .100 \mathrm{~g} \mathrm{~g}^{-1}$, and approximately $92 \%$ of the samples were in full compliance with the standard established by Brazilian legislation. The honey mineral content is directly related to soil type and climatic conditions [36]. The values obtained for this parameter express the quantitative presence of minerals in honey [28].

\subsection{TOTAL PHENOLIC COMPOUNDS AND ANTIOXIDANT ACTIVITY}

\subsubsection{Total phenolic compounds}

In the total phenolic compounds quantification (Table 3), values for Melipona sp. were between 22.59 and $57.71 \mathrm{mg}$ GAE. $100 \mathrm{~g}^{-1}$ of honey, with a mean of 44.21. For honey of Apis sp. The values 
ranged from 27.01 to $53.16 \mathrm{mg}$ GAE. $100 \mathrm{~g}^{-1}$ per 100 grams of honey, with a mean of 38.48 . In literature, when determining the munber of phenolic compounds for Apis mellifera bees found values from 43.34 to 75.47 and for stingless bees found values between 61.28 and $105.59 \mathrm{mg}$ GAE.100 g ${ }^{-1}$ honey [37]. The current legislation does not establish limits for the content of phenolic compounds present in the honey, however, found values in the current literature present on average of $100 \mathrm{mg}$ GAE per 100 grams of honey Comparative data of literature show that when studying several samples of honey produced in the state of Roraima the concentrations ranged from 25 to $50.9 \mathrm{mgGAE} .100 \mathrm{~g}^{-1}$ of honey [20]. To the west of Turkey, found total phenolic contents between 3.54 to $36.6 \mathrm{mgGAE} .100 \mathrm{~g}^{-1}$ of honey [38]. 
Table 3: Mean percentage inhibition index of the DPPH radical and EC50 antioxidant capacity of Apis sp. and Melipona sp.

\begin{tabular}{|c|c|c|c|c|}
\hline Sample & Concentration (mg.mL ${ }^{-1}$ ) & $\begin{array}{l}\text { Mean inhibition of } \\
\text { DPPH radical }(\%)\end{array}$ & $\mathrm{CE}_{50}\left(\mathrm{mg} \cdot \mathrm{mL}^{-1}\right)$ & $\begin{array}{c}\text { Total phenols (mg } \\
\text { GAE.100g } \\
\end{array}$ \\
\hline A1 & $10,20,30,40$ and 50 & $39.40 \pm^{\mathrm{a}}$ & $39.68 \pm^{\mathrm{a}}$ & $27.01 \pm 1.01^{\mathrm{a}}$ \\
\hline A2 & $5,1020,30$, and 40 & $20.40 \pm^{\mathrm{b}}$ & $72.79 \pm^{\mathrm{b}}$ & $44.13 \pm 0.11^{b}$ \\
\hline A3 & $10,1520,25$ and 30 & $32.80 \pm^{\mathrm{c}}$ & $48.32 \pm^{c}$ & $53.16 \pm 0.13^{\mathrm{c}}$ \\
\hline A4 & $1020,25,30$ and 40 & $24.00 \pm^{\mathrm{d}}$ & $78.54 \pm^{\mathrm{d}}$ & $29.27 \pm 0.18^{\mathrm{d}}$ \\
\hline A5 & $1020,25,30$ and 40 & $30.80 \pm^{\mathrm{e}}$ & $63.88 \pm^{\mathrm{e}}$ & $45.17 \pm 0.90^{\mathrm{e}}$ \\
\hline A6 & $1020,25,30$ and 40 & $29.80 \pm^{\mathrm{f}}$ & $43.11 \pm^{\mathrm{f}}$ & $32.15 \pm 0.72^{f}$ \\
\hline M7 & $40,60,80,100$ and 120 & $40.60 \pm^{\mathrm{g}}$ & $109.71 \pm^{\mathrm{g}}$ & $22.59 \pm 1.32^{\mathrm{g}}$ \\
\hline M8 & $15,20,30,40$ and 60 & $40.20 \pm_{\mathrm{g}}$ & $40.74 \pm^{\mathrm{h}}$ & $28.05 \pm 0.56^{\mathrm{h}}$ \\
\hline M9 & $5,1020,30$, and 40 & $23.40 \pm^{\mathrm{h}}$ & $101.26 \pm^{\mathrm{i}}$ & $57.71 \pm 1.73^{\mathrm{i}}$ \\
\hline M10 & $5,10,25,20$ and 25 & $62.00 \pm^{\mathrm{i}}$ & $7.91 \pm^{\mathrm{j}}$ & $45.30 \pm 1.50^{\mathrm{j}}$ \\
\hline M11 & $5,10,25,20$ and 25 & $44.00 \pm^{\mathrm{j}}$ & $15.89 \pm^{\mathrm{k}}$ & $55.52 \pm 1.85^{\mathrm{k}}$ \\
\hline M12 & $10,20,30,40$ and 50 & $29.40 \pm^{\mathrm{f}}$ & $75.16 \pm^{1}$ & $56.09 \pm 1.32^{1}$ \\
\hline
\end{tabular}

Equal letters in the same column did not differ significantly from each other by the Tukey test ( $\mathrm{p}>0.05)$.

Notes: A1: Soure-Apis sp.-Primary forest; A2: Soure- Apis sp.-Primary forest; A3: Salvaterra- Apis sp.- Primary forest; A4: Soure- Apis sp.- Mangrove; A5: Salvaterra- Apis sp.-Mangrove; A6: Soure- Apis sp.- Primary forest; M7: Soure- Melipona sp.-Primary forest; M8: Soure- Melipona sp.- Primary forest; M9: Salvaterra- Melipona sp.- Primary forest; M10: Soure- Melipona sp.- Primary forest; M11: Soure- Melipona sp.- Primary forest; M12: Salvaterra- Melipona sp.- Primary forest 


\subsubsection{Antioxidant activity}

Table 3 also shows the behavior of honey of Apis sp. and Melípona sp., in which samples A1 and $\mathrm{A} 6$ demonstrated better antioxidant inhibition in genus Apis, with $\mathrm{EC}_{50}$ values of 47.18 and $21.14 \mathrm{mg} \cdot \mathrm{mL}^{-1}$. These results are similar to an investigation of the antioxidant capacity of Apis mellifera in nature honey collected in Rio de Janeiro [39], who found $\mathrm{EC}_{50}$ ranged 10.81 to 52.64 $\mathrm{mg} \cdot \mathrm{mL}^{-1}$.

Antioxidants can be classified into primary and secondary. The primers act by interrupting the reaction chain by donating electrons or hydrogen to the free radicals, converting them into thermodynamically stable products and/or reacting with the free radicals, forming the lipidantioxidant complex that can react with another free radical. Secondary antioxidants act by delaying the initiation stage of autoxidation by different mechanisms that include metal complexation, oxygen sequestration, and decomposition of hydroperoxides to form non-radical species, absorption of ultraviolet radiation or deactivation of singlet oxygen [39].

For the results of the Melipona genus, attention is drawn to the samples M10 and M11, which indicated the best inhibitory efficiency index of the DPPH free radical. Treatment with concentrations in the range of 5 to $25 \mathrm{mg} \cdot \mathrm{mL}^{-1}$ promoted an inhibition with a mean of $62 \%$ for the first sample and $44 \%$ for the second, with respective $\mathrm{EC}_{50}$ values of 13.62 and $18.18 \mathrm{mg} \cdot \mathrm{mL}^{-1}$. When comparing the results of the efficient concentration of honey bee Apis sp. and Melipona sp. It was observed that M10 and M11 belonging to the second species were the ones with the highest anti-radical inhibition capacity. In literature [40], studying honey of A. mellifera M. flavolineata and M. fasciculata, produced in Amazonia observed a higher antioxidant capacity $\left(\mathrm{CE}_{50} 6.85\right.$ $\left.\mathrm{mg} . \mathrm{mL}^{-1}\right)$ in the honey of $M$. flavolineata when compared to Apis honey.

\subsection{PEARSON'S CORRELATION}

Regarding the Pearson's correlation (Table 4), there was a strong positive correlation between diastase activity, in relation to the parameters reducing sugars, fructose, ash, acidity. In relation to the phenolic compounds, these presented a positive correlation of high to moderate with the parameters of ash, $\mathrm{pH}$, acidity, and moisture. The $\mathrm{EC}_{50}$ presented a strong positive correlation in relation to fructose, acidity, TP, which is expected since TP may exhibit antioxidant activity. The color had a high correlation with parameters such as fructose, ashes, and acidity. Since the ash content is high, this can influence parameters such as coloring. 
Table 4: Pearson's correlation between the physical, physicochemical and phenolic compounds of bee honey Apis sp. and Melipona sp. from Marajó and Salvaterra

\begin{tabular}{|c|c|c|c|c|c|c|c|c|c|c|c|}
\hline & $\mathbf{R S}$ & Fruc & Ash & pH & Acidity & Moisture & DA & WIS & $\mathbf{T P}$ & $\mathrm{EC}_{50}$ & Color \\
\hline $\mathbf{R S}$ & 1 & 0.51484 & 0.25823 & 0.54804 & 0.10423 & 0.053881 & 0.79856 & 0.50228 & 0.34658 & 0.26895 & 0.10039 \\
\hline Fruc & 0.20882 & 1 & 0.23268 & 0.009593 & 0.10944 & 0.1195 & 0.99956 & 0.58029 & 0.49068 & 0.83643 & 0.80549 \\
\hline Ash & -0.35448 & -0.3728 & 1 & 0.50813 & 0.0096876 & 0.049421 & 0.95358 & 0.23438 & 0.90744 & 0.58433 & 0.99785 \\
\hline pH & 0.19291 & 0.7106 & -0.21209 & 1 & 0.22424 & 0.65383 & 0.45192 & 0.47606 & 0.8441 & 0.36456 & 0.37857 \\
\hline Acidity & -0.49199 & -0.48567 & 0.70996 & -0.3791 & 1 & 0.0020923 & 0.83415 & 0.43471 & 0.66131 & 0.72577 & 0.9691 \\
\hline Moist & -0.56828 & -0.47403 & 0.57717 & -0.14462 & 0.79295 & 1 & 0.18912 & 0.65793 & 0.70829 & 0.78988 & 0.49314 \\
\hline DA & -0.082601 & 0.00017999 & -0.018871 & -0.24027 & -0.067808 & -0.40703 & 1 & 0.62885 & 0.15629 & 0.47793 & 0.58888 \\
\hline WIS & -0.21495 & -0.17784 & -0.37154 & -0.22798 & -0.24922 & -0.14281 & 0.15574 & 1 & 0.53159 & 0.15785 & 0.28159 \\
\hline $\mathbf{T P}$ & -0.29814 & -0.22068 & 0.037681 & -0.063691 & 0.14132 & 0.12086 & 0.43621 & 0.20074 & 1 & 0.74102 & 0.16023 \\
\hline $\mathbf{E C}_{50}$ & 0.34712 & -0.066863 & 0.17598 & 0.28768 & 0.11335 & -0.086233 & -0.22704 & -0.43474 & -0.10684 & 1 & 0.39108 \\
\hline Color & -0.49677 & 0.07971 & -0.00087232 & 0.27972 & 0.012561 & 0.21946 & 0.17388 & 0.33865 & 0.43252 & -0.27273 & 1 \\
\hline
\end{tabular}

RS: Reducing sugars (g.100g-1);Fruc: Fructose (g.100g-1 $)$; Ash (g.100g-1 $)$;Acidity (mEq.100g $\left.{ }^{-1}\right)$; Moist: Moisture (g.100g-1); DA: Diastase activity (Gothe); WIS: Waterinsoluble solids $\left(\mathrm{g} .100 \mathrm{~g}^{-1}\right)$; TP:Total phenols (mg GAE. $\left.100 \mathrm{~g}^{-1}\right)$.

Bold numbers were statistically significant correlations $(\mathrm{p}<0.05)$. 


\subsection{MULTIVARIATE ANALYZES PCA AND HCA}

The application of the multivariate study provided a clear and objective explanation of the correlation and variance of the samples when submitted to grouping with individuals of similar characteristics to each other. According to the chart analysis score (Figure 2), it was observed that Principal Component (PC1 in the first and second quadrant) is the main responsible for separating the larger clusters between the samples, highlighted in the group circled in blue (A2, A4, A6, M7, M8, M10, M11, and M12).

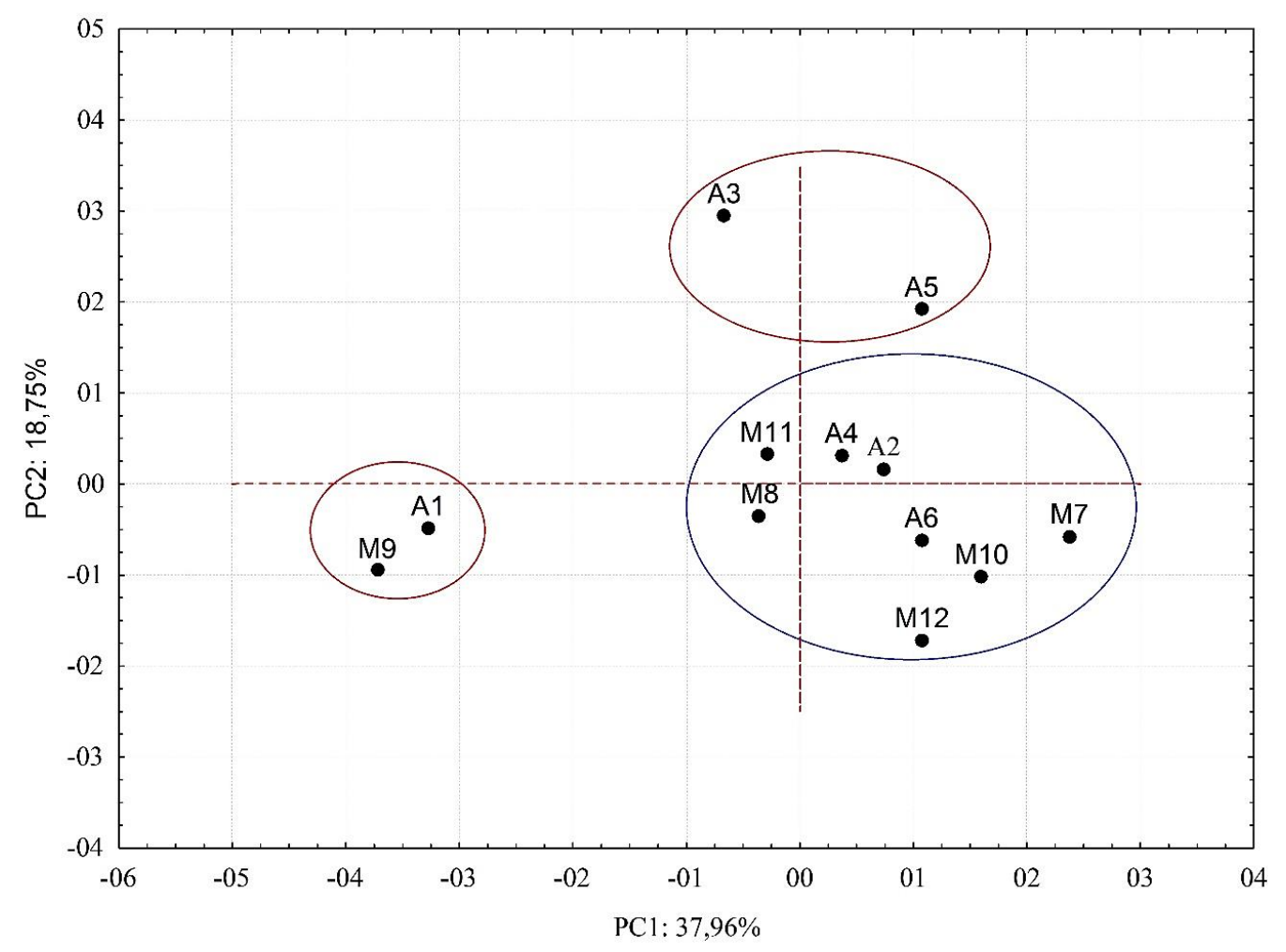

Figure 2: Scores graph for the 12 samples.

The results show that the predominance of bees of the genus Melipona sp. (stingless bees) is evident. This is because this genus frequents the same environment, floral, and the same species of plants to collect nectar from flowers, which directly influences the physicochemical properties of honey. In addition, Montenegro and Fredes (2008) [36] indicates that this degree of similarity to make strong clustering as observed in this work may be related to the way in which the product is treated since it is removed from the hive until you get to the shelf, which demonstrates that the quality and sanitary conditions adopted in the techniques of processing are still in their infancy, the situation is still very common in the region of study due to the lack of training of beekeepers. $\mathrm{Tt}$ can also be observed the focus group (red color) that is influenced by PC2 and PC3 (Principal Component 2 and 3), corresponding to the third and fourth quadrant in the graph (Figure 2), where the predominance is of the honey of the bees of the genus Apis sp. (Bees sting), which implies say that honey produced by this genre tend to have particular characteristics, because they have characteristics that are similar in their distribution in the graph of scores, however, are also influenced by the character of the botanical frequented by this genre to collect the nectar.

The loading graph analyzed (Figure 3 ) shows that the first component (PC1) presented a contrast between the reducing sugar parameters, $\mathrm{pH}$, fructose, total phenols, diastase activity, and insoluble solids. This means that the difference of the parameters can be directly influenced by the 
geographical character of the municipalities, which would justify the divergence of the area observed between the two groups highlighted in the chart of scores.

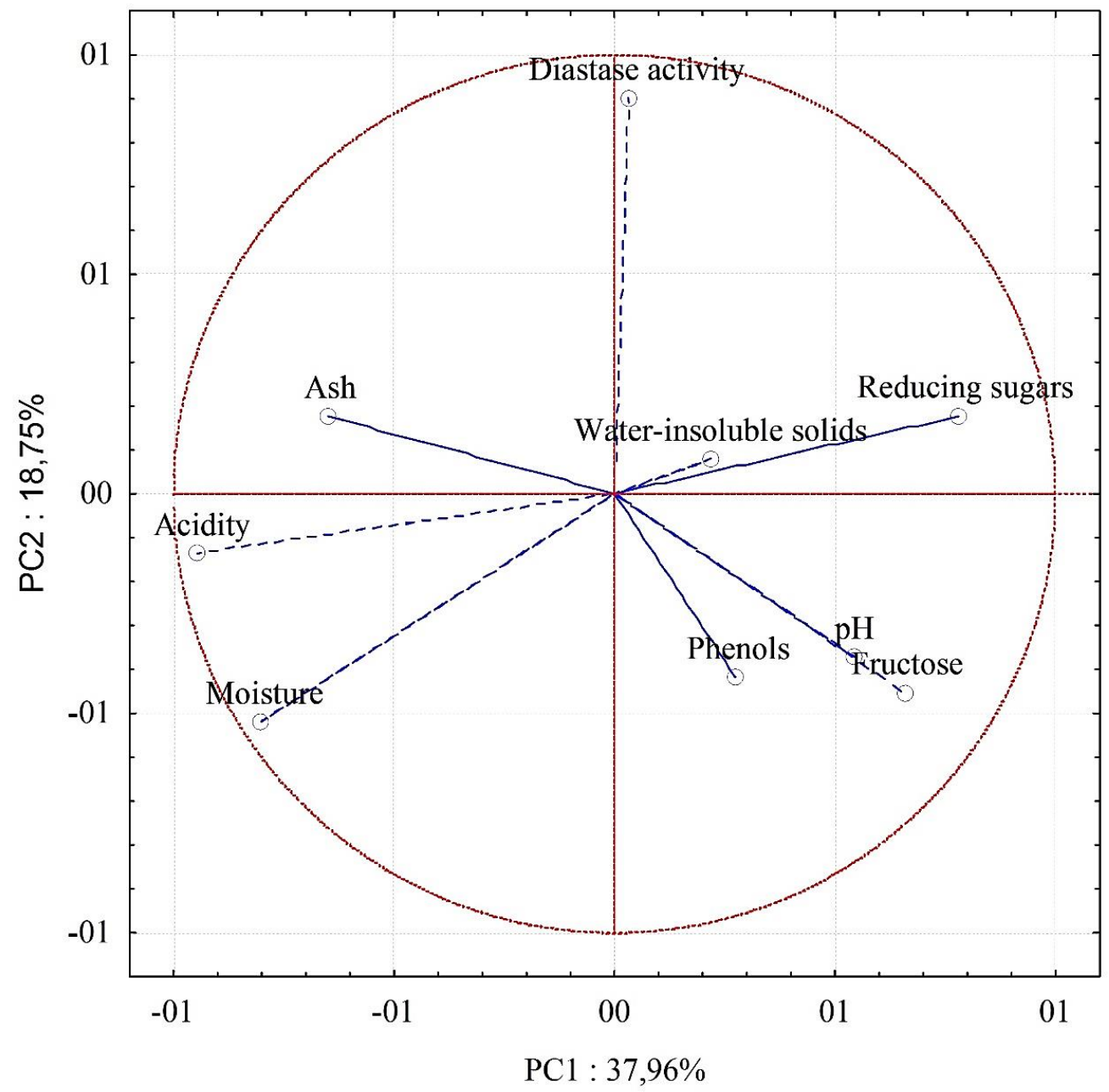

Figure 3: Loadings graph from the main components.

However, the graph also points out that the parameters "reducing sugars", "insoluble solids" and "diastase activity" are responsible for the greater grouping of the samples, although it is not yet possible to establish relationships between these parameters. However, PC2 showed a strong negative correlation with "acidity", "moisture" and "ash", since the quality of the honey might be directly related to processing, extraction conditions and/or apiculture practices.

The observations obtained through the analysis of scores and loadings graphs are corroborated according to the dendrogram graph (HCA) (Figure 4). The graph illustrates the main groups present a simple Euclidean distance, and a high degree of similarity, with a predominance of the genre Apis sp., The groupings are due to the fact of analyzing the degree of similarity and differentiation present in the honey samples, which have as a result a sample profile for honey produced by stings bees and stingless bees. It should be noted that the dendrogram shows that the A3 sample is very isolated, with a lower degree of similarity and a greater Euclidean distance, and the parameter diastase activity is determinant. 


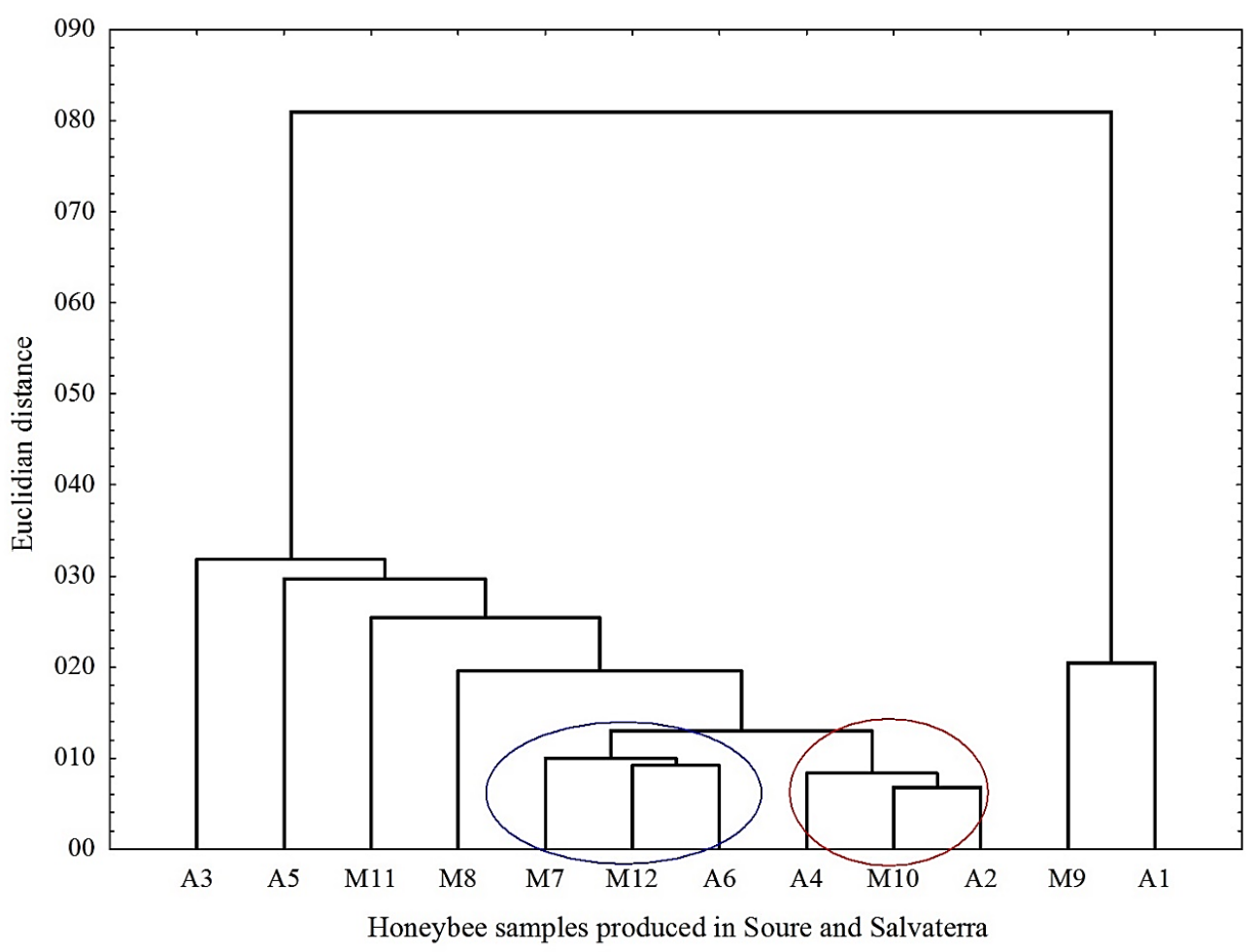

Figure 4: Dendrogram using the Euclidean distance to the 12 samples.

\section{CONCLUSIONS}

The physicochemical and microbiological parameters of all the samples were adequate for use and consumption. The honey of Apis sp. and Melipona sp., through the analysis of PCA and HCA, presented a significant degree of differentiation by the correlation of the parameters: reducing sugars, insoluble solids, and diastase activity. The antioxidant capacity of the honey produced in the municipalities of Soure and Salvaterra presented convenient results both to establish a phytochemical profile of the product marketed in the region and to legitimize popular knowledge about the therapeutic properties of honey. Tukey's analysis showed a significant difference between bees studied and their different origins, Pearson's correlation showed a strong to moderate correlation between the physicochemical parameters of honey. The multivariate analysis proved to be a very useful tool for the analysis of different samples of honey.

\section{ACKNOWLEDGMENT}

The authors acknowledge the University of the State of Pará for all support; to the beekeepers of Salvaterra and Soure for the donation of honey; The PROPESP (Portal da Pró-Reitoria de Pesquisa e Pós-Graduação) for the support for this research through the program of scientific initiation granting scholarships sponsor.

\section{REFERENCES}

1. Ibge. Instituto Brasileiro de Geografia e Estatística: Cidades e Estados. 2017. < https://www.ibge.gov.br/cidades-e-estados.html?view=municipio>

2. Brasil. Ministério da Agricultura. Instrução normativa ${ }^{\circ} 11$, de 20 de outubro de 2000. Estabelece o regulamento técnico de identidade e qualidade do mel. DiárioOficial da República Federativa do Brasil, Poder Executivo, Brasília, DF, 23 out. 2000. Seção 1. p. 16-17. 
3. Brasil. Ministério da Agricultura, Pecuária e Abastecimento. Defesa Animal. Legislações. Legislação por Assunto. Legislação de Produtos Apícolas e Derivados. Instrução Normativa n. 62, de 26 de Agosto de 2003. Contagem de Bolores e Leveduras.

4. Vale MAD, Gomes FA, Santos BRC, Ferreira JB. Honey quality of Melipona sp. bees in Acre, Brazil. Acta Agron. 2018;67(2):01-207. doi:10.15446/acag.v67n2.60836

5. Osés SM, Pascual-Maté A, Fernández-Muiño MA, López-Díaz TM, Sancho MT. Bioactive properties of honey with propolis. Food Chem. 2016;196(1):1215-1223. doi:10.1016/j.foodchem.2015.10.050

6. Juszczak L, Gałkowska D, Ostrowska M, Socha R. Antioxidant activity of honey supplemented with bee products. Nat Prod Res. 2016;30(12):1436-1439. doi: 10.1080/14786419.2015.1057582

7. Ouchemoukh S, Amessis-Ouchemoukh N, Gómez-Romero M, Aboud F, Giuseppe A, FernándezGutiérrez A, Segura-Carretero A. Characterisation of phenolic compounds in Algerian honeys by RPHPLC coupled to electrospray time-of-flight mass spectrometry. LWT-Food Sci Technol. 2017;85(2):460-469. doi:10.1016/j.1wt.2016.11.084

8. Alvarez-Suarez JM, Giampieri F, Brenciani A, Mazzoni L, Gasparrini M, González-Paramás AM. Afrin, S. Apis mellifera vs Melipona beecheii Cuban polifloral honeys: A comparison based on their physicochemical parameters, chemical composition and biological properties. LWT-Food Sci Technol. 2018;87(1):272-279. doi: 10.1016/j.lwt.2017.08.079

9. Nascimento AS, Marchini LC, Carvalho CAL, Araújo DFD, Olinda RA, Silveira TA. Physical-Chemical Parameters of Honey of Stingless Bee (Hymenoptera: Apidae). Am Chem Sci J. 2015;7(3):139-149. doi:10.9734/ACSJ/2015/17547

10. Emater. Dia Nacional do Mel. 2019. < http://tvbrasil.ebc.com.br/sementes/episodio/a-producao-de-melna-regiao-norte>

11. Zhou F, Liu Y, Guo H. Application of multivariate statistical methods to water quality assessment of the watercourses in Northwestern New Territories, Hong Kong. Environ Monit Assess. 2007;132(3):1-3.

12. Vidal MG, Santana NS, Vidal D. Flora apícola e manejo de apiários na região do recôncavo sul da Bahia. Revista Acadêmica: Ci Animal. 2008;6(4):503-509.

13. Vanderzant C, Splittstoesser DF. Compendium of methods for the microbiological examination of foods. 3. ed. American Public Health Association: Washington, 2002.

14. Brasil. Métodos Analíticos Oficiais para Análises Microbiológicas para Controle de Produtos de Origem Animal e Água. 2019.

15. Lutz IA. Açúcar e Produtos Correlatos, 1. ed. Instituto Adolfo Lutz: São Paulo. 2008. 1000 p.

16. Aoac. Official methods of analysis of the Association of Official Analytical Chemists. 16. ed. Ig W. Horwitz: Washington, 1997.

17. Souza RF. Parâmetros físico-químicos, bioquímicos e microbiológicos como descritores de qualidade e discriminação dos méis do Estado do Pará [Dissertação de Mestrado], UFPA, Belém. 2010.

18. Souza BA, Pereira EOL, Santos AS. Adaptação e utilização do reagente de seliwanoff na análise quantitativa de frutose presente em méis de abelha. In: $59^{\circ}$ Reunião anual da sociedade brasileira para o progresso da ciência, 2007. Anais. Belém. 2007.

19. Wilczynska A. Phenolic content and antioxidant activity of different types of polish honey - a short report. Polish J Food Nutr Sci. 2010;60(4):309-313.

20. Pontis JA, Costa LAMA, Silva SJR. Flach, A. Color, phenolic and flavonoid content, and antioxidant activity of honey from Roraima, Brazil. J Food Sci Technol. 2014;34(10):1-14. doi: 10.1016/j.heliyon.2018.e00874

21. Sak-Bosnar M, Sakac N. Direct potentiometric determination of diastase activity in honey. Food Chem. 2012;135(2):827-831. doi: 10.1016/j.foodchem.2012.05.006

22. Statsoft, I. Statistica (data analysis software system), version 7. 2007. www.statsoft.com

23. Souza LS, Barbara MFS, Sodré GS, Santos PC, Almeida AMM, Carvalho CAL. Qualidade microbiológica do mel de Apis mellifera (Hymenoptera: Apidae) produzido na Região Nordeste do Estado da Bahia. Magistra. 2012;24(1):194-199.

24. Sodré GS, Marchini LC, Da Rosa VP, Camargo AC, Moreti C, Carvalho CAL. Conteúdo microbiológico de méis de Apis mellifera (Hymenoptera: Apidae) dos Estados do Ceará e Piauí. Nova Odessa. 2007;64(1):39-42.

25. Codex. Revised Codex Standard for Honey. Codex Alimentarius Commission. 2001.

26. Melo ZFN, Duarte MEM, Mata M. Estudo das alterações do hidroximetilfurfural e da atividade diastásica em méis de abelha em diferentes condições de armazenamento. Rev Bras Prod Agroind. 2003;5(1):8999. 
27. Villas-Bôas JK, Malaspina O. Parâmetros físico-químicos propostos para o controle de qualidade do mel de abelhas sem ferrão no Brasil. Mensagem Doce. 2005;82(1):6-16.

28. Finola MS, Lasagno MC, Marioli JM. Microbiological and chemical characterization of honeys from central Argentina. Food Chem. 2007;100(4):1649-1653. doi: 10.1016/j.foodchem.2005.12.046.

29. Souza BA, Marchini LC, Oda-Souza M, Carvalho CAL, Sodré GS, Alves RMO. Caracterização do mel produzido por espécies de Melipona Illiger, 1806 (apidae: meliponini) da região nordeste do Brasil: 1. Características físico-químicas. Química Nova. 2009;32(2):303-308. doi: 10.1590/S010040422009000200007

30. Freitas WES, Aroucha EMM, Soares KMP, Mendes FIB, Oliveira VR, Lucas CR, Santos MCA. Parâmetros físico-químicos do mel de abelha sem ferrão (Melipona subnitida) após tratamento térmico. Acta Vet Bras. 2010;4(3):153-157. doi: 10.21708/avb.2010.4.3.1777

31. Oliveira ENA, Santos DC. Análise físico-química de méis de abelhas africanizada e nativa. Rev Inst Adolfo Lutz. 2011;70(2):132-138.

32. Almeida-Filho JP, Machado AV, Alves FMS, Queiroga KH, Cândido AFM. Estudo físico-químico e de qualidade do mel de abelha comercializado no município de pombal - PB. Rev Verde. 2011;6(3): 83-90.

33. Gomes PWP, Muribeca AJB, Silva MDB, Carneiro JS, Souza RF. Avaliação físico-química e microbiológica de méis de abelhas comercializados no município de Soure - Marajó - Pará. Enciclopédia Biosfera. 2015;11(22):2920-2933. doi:10.18677/Enciclopedia_Biosfera_2015_013

34. Modesto-Junior EN, Gomes PWP, Muribeca AJB, Assis RN, Souza RF. Perfil sensorial e de qualidade do mel comercializado no município de Salvaterra - Ilha do Marajó - Pará. Enciclopédia Biosfera. 2014;10(19):1448-1457.

35. Santos DC, Oliveira ENA, Martins, JN, Albuquerque EMB. Qualidade físico-química e microbiológica do mel de Apis melífera comercializado na cidade de Russas, CE. Tecnol Ci Agropec. 2011;5(1):41-45.

36. Montenegro G, Fredes C. Relación entre el origen floral y el perfil de elementos minerals en mieles chilenas. Gayana Bot. 2008;65(1):123-126. doi: 10.4067/S0717-66432008000100014

37. Lira AF, Sousa JPLM, Lorenzon, MCA, Vianna CAFJ, Castro RN. Estudo comparativo do mel de Apis mellifera com méis de Meliponíneos. Acta Vet Bras. 2014;8(3):169-178. doi: 10.21708/avb.2014.8.3.3560

38. Özkök A, D'arcy B, Sorkun K. Total Phenolic Acid and Total Flavonoid Content of Turkish Pine Honeydew Honey. J Prod Med Sci. 2010;2(2):65-71.

39. Lianda RLP, Sant'Ana LD, Echevarria E, Castro RN. Antioxidant Activity and Phenolic Composition of Brazilian Honeys and their Extracts. J Braz Chem Soc. 2012;23(4):618-627. doi: 10.1590/S010350532012000400006

40. Oliveira PS, Müller RCS, Dantas KGF, Alves CN. Ácidos fenólicos, flavonóides e atividade antioxidante em méis de Melipona fasciculata, M. flavolineta (Apidae, Meliponini) e Apis mellifera (Apidae, Apini) da Amazônia. Química Nova. 2012;35(9):1728-1732. 